\title{
MEANING AND TRANSLATION
}

\author{
Andy Bayu Nugroho \\ State University of Yogyakarta
}

\begin{abstract}
Translation is an effort of finding equivalent meaning of a text into the second language. We emphasis meaning equivalence since in translation meaning is the object to be rendered from the source language text into the target language text. In this case, translator is faced with a text as units of meaning in the form of sets of words or sentences.

The main question in translation is of meaning which always appears in the process of translation, not translation as a product of the process. Translating a text from the source text (ST) must consider the closest natural equivalent meaning. It implies that the meaning of the target text must be equivalent with that of the source.

Meaning is classified into two kinds, referential meaning and connotative meaning. A translator must be aware of which meaning is possibly intended by the author. Beside, it should also be paid attention on the components embedded in a certain unit of meaning. By understanding the components of meaning of the source language expressions a translator can make the best decision related to the components.
\end{abstract}

Keywords: units of meaning, equivalence 


\section{A. On Translation}

Generally, translation is a process of rendering meaning, ideas; or messages of a text from one language to other language. There are some considerations which follow this process, which mainly related to the accuracy, clarity and naturalness of the meaning, ideas, or messages of the translation. It mearis that it is an important thing to consider whether the readers of the target text accept equivalent information as the readers of the source text do. These considerations are clarified in some definition of translation stated by some experts.

One of the most prominent definitions of translation is stated by Newmark (1988: 5) who defines translation as "rendering the meaning of a text into another language in the way that the author intended the text". This definition stresses on rendering meaning of the source language text into the target language text as what is intended by the author.

Hatim and Munday (2004: 6) define translation as "the process of transferring $a$ written text from source language (SL) to target language (TL)". In this definition they do not explicitly express that the object being transferred is meaning or message. They emphasis on translation as a process.

Nida and Taber (1982: 12), on the other hand, state that "translating consists in reproducing in the receptor language the closest natural equivalent of the source language message". This definition is more comprehensive than the previous ones. Nida and Taber explicitly state that translation is closely related to the problems of languages, meaning, and equivalence.

From the definitions mentioned above, it is found that translation is a process which is intended to find meaning equivalence in the target text. Rochayah Machali (2001) and Mona Baker (1992) underline the term meaning equivalence because it is the meaning which is transferred in the target language. In this case, translators are faced with text as unit of meaning in the form of sets of words or sentences. This means that language which is used is unit of meaning in discourse which can be understood by the participants of the communication (Machali, 2007).

So, the main problem in the process of translation is about meaning which will occur when the process is in progress, not translation as a product. Hatim and Munday (2004: 34) also suggest that "one of the key problems for the analyst was in actually determining whether the source text meaning had been transferred into the target text". It is clear here that meaning is the key problem: whether meaning of the source language text is accurately transferred into the target language text. 


\section{B. On Meaning}

Translation is not merely concerning on meaning as a unit of lexical meaning. The process of rendering meaning involves some aspects as diction, grammatical structure, communication setting, and cultural context of the source text. Meaning of the source and target texts must be equivalent.

The meaning equivalence is involved by, at least, language. The system of rules in one language, which is different from other language, will have role for the translator in his or her decision making in the process of translation. For example, in this case, is the process of translation which involves Indonesian and English language. Both languages have different system on the structure of noun phrase. Noun phrases of English language usually follow the structure of modifier + noun head. While that of Indonesian language usually follow the rule of D-M (Diterangkan Menerangkain) where modifier comes after the noun head. To clarify this fact, this comparison can be the example. The English phrase 'a beautiful girl' is translated into 'seorang gadis cantik' in Indonesian language.

Meaning of a phrase in one language cannot always be translated in the way as the example above. The Indonesian phrase 'kambing hitam' is not always translated as 'black 'goat' in English language. If it means 'a goat which is black', the phrase can be translated as 'a black goat'. However, if it has a specific meaning 'a person who is blamed for something that someone else has done', it will be equivalent with the English phrase 'scapegoat'.

\section{Kinds of Meaning}

Nida and Taber (1982: 56) classifies meaning into two classes, referential meaning and connotative meaning. Magdy M. Zaky in 'Translation and Meaning' also differentiates meaning into two categories, referential meaning and associated meaning (which includes connotative meaning) (http://accurapid.com/ journa//14theory.htm, updated at 02/26/2005). Zaky states, "there is a distinction between conceptual meaning, on the hand, and connotative, stylistic, affective, reflected, and collocative types of meaning on the other hand. Thus, we classify the last five types of meaning under one general category of associated meaning". We will concern with referential meaning and connotative meaning in this paper.

\section{Referential Meaning}

Referential meaning is word as symbol which refers to an object, process, abstract thing, and relation. Zaky (2005) mentions that referential meaning is also known as 'the meaning of reference, is often referred to as the "referential" meaning, the "lexical" meaning, the "conceptual" meaning, or the "denotative" meaning'. Giving the meaning of a word referentially, a translator must be aware of any markers appear in the text. There are two markers that can be used to give meaning of words, syntactic marking and semotac marking. 


\section{a. Syntactic marking}

In some cases, the meaning of a word is governed by their grammatical structure. Here are the examples.

\begin{tabular}{|l|l|l|l|}
\hline \multicolumn{1}{|c|}{ I } & \multicolumn{1}{c|}{ II } \\
\hline 1 & He picked up a stone. & 1 & They will stone him. \\
\hline 2 & He saw a cloud. & 2 & The quarrel will cloud the issue. \\
\hline 3 & She has a beautiful face. & 3 & He will face the audience. \\
\hline 4 & He fell in the water. & 4 & Please, water the garden. \\
\hline
\end{tabular}

From the examples above, it can be seen that in column I the words 'stone', 'cloud', 'face', and 'water' are nouns which are usually translated into 'batu', 'awan', 'wajah', dan 'air'. While in column II, the underlined words are not nouns, but verbs which in Indonesian language mean 'melempar (dengan batu)', 'memperkeruh', 'menghadapi', and 'menyiram'. In this case, grammatical structure of each word refers to the intended meaning explicitly.

\section{b. Semotac marking}

Meaning of a word is also determined by its relationship with other words in a certain context. In other words, semotac environment differentiates meaning. Here are the examples.

\begin{tabular}{|l|l|l|l|}
\hline \multicolumn{3}{|c|}{ I } & \multicolumn{1}{|c|}{} \\
\hline 1 & The horse runs fast. & 1 & The water runs through the path. \\
\hline 2 & Your hand is dirty. & 2 & All hands up! \\
\hline
\end{tabular}

The words 'runs' in sentence 1 in column I and II have different meaning because they have different subjects. In column I, the word 'runs' means 'berlart' while in column II, it means 'mengalir'. The words 'hand' in example 2 are also different in meaning.

\section{Connotative Meaning}

Understanding meaning of a word is not merely based on the referred object of the word. Sometimes, a translator also needs to give emotional reaction to the word. The reaction might be strong, weak, positive or negative. this kind of meaning is closely. related to individual emotional reaction which, then, is named as connotative meaning. In other words, giving the meaning of a word is not merely from its concrete or abstract dimension, but it also involves the sender's emotional condition. There are three main principles to understand connotative meaning. They are: 


\section{a. The relationship between the word and the speaker}

'When certain words become very closely related with certain types of speakers, this will be well accepted by the member of the group. For examples are words which are used and understood by members of certain social class, level of education, and religion.

\section{b. Condition of the speaker}

The same word expressed by the same speaker but in different condition or setting may rise different connotative meaning. Some expressions are related to certain environments as in. court, police station, market, tourism objects, etc. for illustration, there is a woman who met her friend while she is shopping in a market. She told a story to her friend that last night there were a robbery at her neighbor's house. Her friend may respond it as new information that warns her to be more careful at home. Different respond will appear when the woman told the story to a police officer. This will become a report to be seriously handled.

\section{c. Linguistic factor}

Parallel words which are always in pairs with other words give different various connotations. The word 'green', for example, when it is in pair with the following words have different meaning.

$\begin{array}{ll}\text { green with envy } & \rightarrow \text { cemburu } \\ \text { green at the gills } & \rightarrow \text { pucat } \\ \text { a green worker } & \rightarrow \text { pekerja baru } \\ \text { a green fruit } & \rightarrow \text { buah yang masih muda }\end{array}$

The word 'green' in some examples above are in fact a kind of colour. The word has different meaning when it occurs before certain words that the receivers might react differently.

\section{Elements of Meaning}

Larson (1984: 6) states that there are some characteristics of language which involve the process of translation. By knowing the elements of meaning of the source language, translators can make the right decision related to these elements. The elements are described below.

\section{Plural system}

English and Indonesian language are different in marking plural nouns. In written communication, English uses inflectional morpheme $-s$ or $-e s$, or adds phoneme /-s/, /-z/, or /-is/ in spoken. Some irregular forms are also exist. Whle in Indonesia, markers of plural nouns are shown by using repetition. For example: 


English
fruit $\rightarrow$ fruits $\begin{aligned} & \text { Indonesian } \\ & \text { book } \rightarrow \text { books } \rightarrow \text { buah-buahan } \\ & \text { candy } \rightarrow \text { candies } \\ & \text { child } \rightarrow \text { children }\end{aligned}$

\section{One form with many alternative meaning}

A word has a primary meaning, that is the meaning which at the first time is got by the receiver or reader. The second or altemative or connotative meaning is one which is affected by the context. The examples below may clarify this.

The boy runs fast.

He runs his eyes over the crowd.

Life must run its course. $\rightarrow$ Anak itu berlari dengan cepat.

$\rightarrow$ Ia melayangkan paridangannya pada keruminan itu

$\rightarrow \quad$ Hidup harus menempuh jalannya sendiri.

\section{Grammatical marker}

In this case, grammatical marker has two functions, primary and secondary functions. The word 'on', to give an example, in English indicates some meanings. This fact is described below.

Sita found a book on the table.

Sita found a book on Biology.

Sita found a book on Wednesday.

The word 'on' in the examples above indicates 'position' or 'location', 'about' and relation of time which in Indonesian are translated as 'diatas', 'tentang', or 'pada'.

\section{E. Problem of Non-Equivalence}

Some problems of non-equivalence at word level, according to Baker (1992: 17), is related to cultural differences, where there is no equivalent words in both source and target language. Source and target language make differences in meaning, or where there is no specific term in the target language. This is what so called culture specific.

\section{Cultural difference}

Newmark (1988: 94) defines culture as "the way oflife and its manifestations that are peculiar to a community that uses a particular language as its means of expression". Some words in the source language may express concepts which absolutely cannot be understood by the native of other language. The concept can be concrete or even abstract thing related to religion, social tradition, or meals. 
Alejandra Patricia Karamanian in 'Translation and Culture' (http: //accurapid.com/joumal/19culture2.htm, updated on: 02/26/2005) states:

We are not just dealing with words written in a certain time, space and sociopolitical situation; most importantly it is the "cultural" aspect of the text that we should take into account. The process of transfer, i.e., recoding across cultures, should consequently allocate corresponding attributes vis-à-vis the target culture to ensure credibility in the eyes of the target reader. (2007).

The following example is taken from Opera Kecoak which is used by Machali

SL: Panggil saya 'Mas'.

TL: Call me 'honey'.

The word 'Mas' in the dialog above is translated into 'honey' in English. However, in different context, of course, the word 'Mas' cannot be translated as 'honey', for example when it is used to address one's older brother.

\section{No equivalent word in the target language}

Sometimes a word expresses a concept which can be understood in the target language but there is no exactly equivalent expression. The word 'standard' in Indonesian is represented by some meaning as 'ukuran' and 'patokan', but they are not fully equivalent with the meaning of the word in the source language.

Other example is given by Machali (2007):

SL:(Kepada wartawan)

Saudara-saudara, acara ini sudah selesai. Bapak yang mulia dan tamunya hendak menikmati acara yang sifatnya lebih pribadi. Mohon maaf. Press-release akan dibagikan nanti sore secara tertulis. Juga amplopnya sekalian.

TL (for the underlined expressions)

You will get a written press release by this evening and, of course, a little something extra as a sign of our appreciation for your hard work

In the translation version, the connotative meaning in the word 'amplop' is translated into a more neutral expression in English (see the bold expression), even the phrase 'your hard work' seems to be like an irony. It seems that the translator considers that the target readers will understand the phrase 'hard work' as the. realization of the connotative meaning of 'amplop'. This technique is more relevant to the target readers than using the word 'envelope' literally. 


\section{Source and Target Language Make Differences in Meaning}

A translator sometimes makes different meaning of the source and target text. One expression in the source text might be differently expressed in the target text. As an example, in the sentence 'She was going out in the rain', it can be understood differently in Indonesian: 'Dia pergi keluar tanpa tahu kalau hujan sedang turun' or'Dia sengaja pergi keluar meskipun hujan sedang turun'. In this case, the translator must be quite aware of the context in the source text.

\section{There is No Specific Expression in the Target Language}

English has some specific term for 'house' as 'bungalow', 'cottage', 'villa', 'hall', 'lodge', and 'mansion'. Javanese, on the other hand, also has some specific terms related to plants as 'manggar', 'bluluk', 'cengkir', 'degan', 'klopo', and 'cumplung' which is not found in Indonesian and English.

\section{F. Conclusion}

Translation is basically a process of conveying meaning or meaning of a givenlinguistic discourse of a language into other language, more than just transferring words or grammatical structure of the SL. The meaning of a word or set of words can be well understood because of its role in the whole linguistic expression in where they occur. For this reason, the meaning of a word is not only determined by the referred object or idea, but it is also governed by the use of the words or phrases in a certain way; context, and effects.

When we try to find the equivalence, we are faced with text as unit of meaning, even in the form of sets of words or sentences. It is important to note that language is used as a communication means, so in translating a text we should remember the principle of "A text is a whole entity, to be translated as a whole". 


\section{Bibliography}

Baker, Mona (1992). In Other Words, A Coursebook on Translation. London:

Routledge

Hatim dan Munday (2004: 6) Translation, An Advanced Resource Book. London:'

Routledge.

Karamanian, Alejandra Patricia (http://accurapid.com/journal/19culture2.htm),

Translation and Culture updated on: 02/26/2005

Larson (1984: 6) Meaning Based Translation: A Guide to Cross Language Equivalent. Boston: University Press of America.

Machali, Rochayah (2007). Campur Tangan Penerjemah: 'mengkhianati' teks asli? Makalah dalam Seminar Nasional Penerjemahan. FBS UNY

Newmark (1988). A Textbook of Translation. Hertfordshire: Prentice Hall International

Nida, Eugene A and Charles R. Taber (1982). The Theory and Practice of Translation. Leiden: E.J. Brill.

Zaky, Magdy M. (http://accurapid.com/journal/14theory.htm) Translation and. Meaning Last updated: 02/26/2005 